\title{
Factors Influencing Auditors' Professional Scepticism: Malaysian Evidence
}

\author{
Razana Juhaida Johari ${ }^{1 *}$, Tarmizi Mohd Hati ${ }^{2}$, Sayed Alwee Hussnie Sayed Hussin ${ }^{3}$ \\ ${ }^{1}$ Faculty of Accountancy, Universiti Teknologi MARA, Malaysia \\ ${ }^{2}$ Majlis Peperiksaan Malaysia, Persiaran 1, Malaysia \\ ${ }^{3}$ Jabatan Audit Negara, Pusat Pentadbiran Kerajaan Persekutuan, Malaysia
}

Received August 23, 2021; Revised November 9, 2021; Accepted December 9, 2021

\section{Cite This Paper in the following Citation Styles}

(a): [1] Razana Juhaida Johari, Tarmizi Mohd Hati, Sayed Alwee Hussnie Sayed Hussin , "Factors Influencing Auditors' Professional Scepticism: Malaysian Evidence," Universal Journal of Accounting and Finance, Vol. 10, No. 1, pp. 243-253, 2022. DOI: 10.13189/ujaf.2022.100125.

(b): Razana Juhaida Johari, Tarmizi Mohd Hati, Sayed Alwee Hussnie Sayed Hussin (2022). Factors Influencing Auditors' Professional Scepticism: Malaysian Evidence. Universal Journal of Accounting and Finance, 10(1), 243-253. DOI: 10.13189/ujaf.2022.100125.

Copyright $(2022$ by authors, all rights reserved. Authors agree that this article remains permanently open access under the terms of the Creative Commons Attribution License 4.0 International License

\begin{abstract}
The practice of professional scepticism is an essential element to audit quality. An auditor is required to have a sceptical attitude to minimize the mistakes made during the examination or investigation of financial statements. However, the occurrences of corporate scandals among the audited companies had affected the public's confidence and the blame was shifted on auditors for ineffective application of professional scepticism. Therefore, this study examines the potential factors that influence auditors' professional scepticism including auditors' trust, locus of control, and fraud risk assessment. The primary data were collected through the questionnaires given to the auditors from public accounting firms in Kuala Lumpur. The results of this study show that the attitude of professional scepticism has no significant bearing on auditors' level of competence (knowledge and experience). Whereas, there are positive relationships between auditors' trust, fraud risk assessment, work internal locus of control and professional scepticism.
\end{abstract}

Keywords Auditors' Professional Scepticism, Competence, Trust, Locus of Control, Fraud Risk Assessment, Malaysia

\section{Introduction}

The accounting profession is considered as the "gatekeeper" in safeguarding the investing public. It is perceived as one of the highest standards of integrity among the professional service areas. However, the great accounting scandals which occurred around the globe have changed the accounting industry dramatically. The scandals of the famous Enron, filing bankruptcy with almost $\$ 62$ billion (in assets) in early 2001, are followed by WorldCom's bankruptcy with around $\$ 100$ billion in assets. Accounting scandals in relation to high profile companies around the world as well as cases in Malaysia such as the 1MDB, Felda Global Ventures Holding Berhad and PKFZ Berhad, had affected the public's trust and expectations.

The issue of accounting scandals involving financial fraud is exacerbated with the public accounting firms' failure to detect fraudulent reporting. It is claimed that the lack of professional scepticism performed by the auditors had led to audit failures and audit insufficiencies [1,2]. The PCAOB report in 2008 indicated that, in many cases of fraud, "failures to apply sufficient professional scepticism were significant factors that allowed the deficiencies (fraud) to occur". Auditors' failure in detecting fraud during audit engagement have encouraged the regulators to attain a higher degree of professional scepticism among the audit practitioners.

Professional scepticism is a trait that consists of critical assessment and a questioning mind on audit evidence. In defining professional scepticism, several academic literatures seem to have a neutral perspective such as Hurtt [3] who defined professional scepticism from the angle of 
numerous sceptics' characteristics (e.g. self-confidence, questioning mind, and suspension of judgement) that further emphasized on pursuing and doubting rather than on a specific direction of doubt. Nevertheless, other literatures seem to take on more of the presumptive-doubt perspective, seeing auditors as demonstrating more professional scepticism when they consider that there were materially misstatements of financial statements or when auditors collect more evidence to ensure that material misstatement does not occur. Nelson [4] stated that professional scepticism can be concluded as a product of auditors' judgement, but professional scepticism is exposed by sceptical action or behaviour, which is an element of auditors' performance.

Empirically, it is still unclear what has caused this lack of professional scepticism and if so, what factors led to the lack of professional scepticism. Previous studies had highlighted several factors that contributed to this failure. For example, various areas of failure in the audit process might have been caused by faulty planning (in the planning phase), faulty supervision (during the auditing phase), and those attributable to inappropriately questioning specific measurements, disclosures, and management representations [5]. Unfortunately, another factor that led to the lack of professional scepticism is the lack of auditors' understanding on the elements that might influence their professional sceptical attitude. Thus, to solve this problem, this study purposely identifies and examines the relevant elements that might contribute to the enhancement of auditors' professional scepticism.

One of the influencing factors to professional scepticism is auditors' competence. A lack of auditors' competence might affect the proper exercise of professional scepticism. For example, the use of relatively inexperienced staff auditors in public accounting who lacks relevant knowledge and expertise can limit their capability to successfully apply professional scepticism. Auditors with decent and respectable knowledge and experience tend to be more sceptical when making judgements and decisions. The more competent an auditor, the more he or she can evaluate the proficiency level of evidence with more in-depth and well-defined.

In addition, auditors' trust is a key factor underlying the formation of strong self-confidence to achieve success at work. It can be explained as a generalized expectation of a person or a group toward the verbal or written statement of another person or group that can be relied upon [6,7]. Trust can influence the auditors' professional scepticism. The basic assumption on the relationship between trust and professional scepticism is that an auditor is assumed to be more sceptical if he has a lower level of trust $[3,8]$. However, sometimes excessive trust on certain evidence or auditee's explanation or statement is of little worth since it can obscure the overall audit requirement program.

Furthermore, research by Lazarusli and Ratri [9], Clark and Schurer [10], and Nyhus and Pons [11] showed that the influence of locus of control is also considered as a cause of the aforementioned financial scandals. Locus of control can be defined as a personality behaviour which relates to individuals' perception on the reasons of incidences that happen in their lifetime. An auditor's self-personality (internal locus of control) reflects how the person responds to his environment. Generally, a person with an internal locus of control believes he has control over his destiny, and therefore, is accountable for his decisions and deems himself more confident in his own abilities, skills, and efforts which ultimately determine his experiences. In contrast, a person with an external locus of control thinks that his destiny is controlled by external factors such as chance, fate, luck, and power [12] and tends to behave and act unethically, compared to those (a person with an internal locus of control) who can control their behaviour [13].

Another element is auditors' fraud risk assessment. Hoffman and Patton [14] and Braun [15] stated that one of the factors that led to the lack of professional scepticism is lack of auditors' necessary knowledge to recognize significant risk factors during an audit process. A research by Payne and Ramsay [16] proved that professional scepticism is affected by fraud risk assessment provided by the employer as guidelines for auditors in conducting audits in the field. This viewpoint is supported by Kopp [17] and Quadackers [18] who proved that the auditors who were given high fraud risk assessment by their superiors tend to be more sceptical than the auditors of low fraud risk assessment.

By considering the factors of auditors' competence, trust, locus of control, and fraud risk assessment as well as enhancing the study on auditors' professional scepticism in Malaysia, this current study has been conducted on Malaysian auditors. The result from this study offers input to academics on professional scepticism, especially in auditing profession. This study seeks to provide a better understanding on the factors that influence auditors' professional scepticism to facilitate an enhancement of auditors' professional scepticism conduct to improve their expertise in auditing and the quality of audits.

\section{Significance of the Study}

Professional scepticism is essential for auditors to minimize errors throughout their audit assignment and enhance the level of public trust on the quality of audit profession. Auditors can also be expected to practice more professional scepticism if they demonstrate high standards of professional work. There is still insufficient explanation regarding professional scepticism among auditors. The lack of understanding of significant factors which support the enhancement of professional scepticism prevents auditors from applying an appropriate level of professional scepticism when conducting audit activities.

Additionally, the issue of professional scepticism attracts the attention of the public and other stakeholders. 
There is a lack of academic writing which explains the model or concept of scepticism other the uncertainty of the procedures on the application of scepticism. Hurtt [19] stated that there is still not much literature defining the traits and concept of scepticism in auditing research. Therefore, future research should be conducted to find out the factors that affect professional scepticism attitudes and behaviour. An identification of the relevant factors that influence professional scepticism may assist educators and practitioners in improving auditors' judgment and decisions.

Similarly, in Malaysia, there is still a lack of studies on auditors' professional scepticism. A research by Hussin and Iskandar [20] was conducted on the validity of the Hurtt scepticism scale in the perspective of different audit work requirement (based on Malaysian data). The result showed that five scepticism traits are relevant except for suspension of judgment. The results also suggested that variances may occur across different countries due to differences in environment.

To add on to the research of professional scepticism, this current study specifically focuses on the analysis and examination of relevant factors that affect the degree of auditors' professional scepticism. This main reason for the focus of the study is due to the lack of auditors' understanding of significant factors that enhance their professional scepticism. For this purpose, several elements have been identified and selected as relevant factors that may be related to the level of professional scepticism. These are auditors' competence, trust, locus of control and fraud risk assessment. The objective of this study is to identify and examine the significant factors that influence professional scepticism.

\section{Literature Review}

\subsection{Defining Professional Scepticism}

As defined by the International Standards on Auditing (ISAs), professional scepticism is an attitude of critical assessment and a questioning mind towards audit evidence to alert the possibility of misstatements which might come from fraud or human error. Professional scepticism integrates the characteristics associated with being a sceptic in a professional setting and appliance of due diligence and a standard of care. Being a sceptic is frequently related with skills of a questioning mind, probing reflection, careful observation, and a suspension of belief.

Shaub [8] described professional scepticism as an attitude reflective of suspicion. Professional scepticism is also essential to balance suspicion and trust. For example, Deutsch [21] proposed that dysfunctional behaviour will happen if there is extreme suspicion and/or extreme trust. Thus, it is important for auditors to practice an appropriate level of scepticism during all phases of the audit and the risk assessment phase. Additionally, an auditor is required to examine beyond the obvious in the investigation to reveal information and relationships. He must look beyond the face value of an evidence presented or revealed to find out what is really going on. Therefore, an auditor is obliged to adopt scepticism, especially in identifying fraudulent financial statements as stated in paragraphs 24 to 26 of ISA 240.

Although enhancing professional scepticism is essential, accounting research revealed that even auditors who are more sceptical are still unable or fail to identify fraud $[22,23]$. Excessive professional scepticism, unfortunately, may also be disadvantageous to the accounting industry. Although professional scepticism has several constructive benefits including reducing the possibility of audit failure and bad publicity for auditor engagements, a high level of scepticism may raise the cost of an audit across a portfolio of engagements [24]. A research by Nelson [4] supported the statement that a higher level of auditor's degree of professional scepticism can ultimately lead to an increase in the cost of audits, as more tasks will be performed to attain adequate support and proof of management's assertions. Nelson also stated that the planning and constructing process of audit might be overly expensive and inefficient.

\subsection{Influencing Factors on Auditors' Professional Scepticism}

\subsubsection{Competence}

In this current study, auditors' competence is defined as the combination of auditors' knowledge, skills, experiences, and attitudes which allow an audit assignment to be carried out objectively, carefully, and thoroughly. Auditors who have more knowledge about the field can outline, understand, and detect different problems, as well as locate the cause of the errors easily. Carpenter et al. [25] discovered that novice auditors with a respectable knowledge of fraud can discover fraud better compared to auditors who lack such knowledge.

A better level of knowledge equips auditors with a propensity to produce high-quality assumptions and make accurate assessment of said assumptions when confronted with unresolved audit findings [26,27]. Several studies have proven that auditors tend to retain knowledge that assists them to alter considered risk in a reaction to client and firm characteristics such as the integrity of management, financial health, and internal control quality. For example, Herawaty and Susanto [28] stated that, auditors' knowledge of errors is positively significant to consider and determine the level of misstatement in financial reporting. Therefore, it is assumed that an auditor's knowledge of fraud influences their professional scepticism.

To identify and develop ways to address audit issues, the auditors' knowledge relies on professional maturity. Consequently, it can be said that professional scepticism 
develops over time. An auditor with significant experience is likely to have better professional senses, become more instinctive, and have a high degree of professional scepticism. The auditors' knowledge, derived from invaluable experience, can enhance their professional scepticism in detecting and analysing frequencies of evidence patterns and errors that suggest an amplified misstatement risk [29,30]. Previous studies have proven that experienced auditors own reasonably accurate knowledge of more mutual error causes and error effects [26] and that knowledge grows with experience [27]. Additionally, several studies show that auditors with particular experience in other areas are likely to identify potential errors [31-33] and as a result, adjust their audit planning decisions [33,34].

Conversely, previous research also suggests that knowledge cannot always heighten professional scepticism. Noviyanti and Winata [35] which indicates that knowledge of fraud does not influence auditors' professional sceptical behaviour if they have a weak sceptical attitude. Auditors with a high level of experience are more inclined to consider that non-errors are the more likely explanations for audit findings [36,37] and can possibly compromise professional scepticism [38]. Furthermore, experience has a substantial effect on the accuracy of auditor's judgement and enhances their competency to analyse the information and generate numerous plans in special conditions. Contrastingly, Shaub and Lawrence [39] indicated that auditors who are more experienced have greater expectations that non-errors describe audit findings can explain since that staff auditors are more sceptical in their behaviours and judgements compared to more experienced auditors. Therefore, a high level of knowledge can weaken professional scepticism if auditors learn to accept non-error clarifications and ignore crucial missing evidence.

\subsubsection{Trust}

Trust is the basis for an individual to be open for criticism and suggestions from others. People will accept advice and criticism from others as they trust that the opinion of the related problem is competent, reliable, and relevant. Kopp et al. [17] stated that confidence (trust) in the auditor-client relationship will affect professional scepticism. Auditors appear to pursue a balance in client relationships between trust and suspicion. This balance between trust and suspicion is essential as it possibly affects the audit plan from the audit procedures designated [40,41]. Kee and Knox [42] suggest that a slight amount of suspicion might facilitate if it does not distract suspicion. Particularly, auditors with a low level of trust will be more focused or give more attention to evidence provided and reinforce the belief that intentional misstatement has occurred.

\subsubsection{Locus of Control}

There are two parts of the human personality, the internal locus of control and external locus of control.
People with an external locus of control believe that things are outside of their self-control, such as opportunity or the existence of an external power that can determine what results will take place. People with an external locus of control tend to be less depressive and independent. Conversely, there is a general expectation that the actions of an individual with an internal locus of control will bring about the desired result. Nonetheless, both behaviours are more success-oriented since they believe that they can produce positive outcomes and tend to be high achievers [43].

The locus of control construct has not been comprehensively studied in previous research on auditor scepticism. Tsui and Gul [44] stated that internal locus of control has a significant influence on auditors' judgments and decisions in an audit conflict situation compared to external locus of control, which is more likely to disregard unrecorded liabilities, as preferred by management. Donnelly et al. [45] also found that external locus of control auditors is more tolerant of dysfunctional audit behaviour such as the gathering of insufficient evidence or a premature sign-off. Normally, auditors with internal locus of control are allied with a higher degree of overall job performance because of their ability to effectively control the audit environment by identifying the issues as compared to the external locus of control auditors. Thus, this study expands on existing research by examining the influence of locus of control on auditors' sceptical judgments and decisions.

\subsubsection{Fraud Risk Assessment}

Risk assessment is an element of the risk management process, which covers the entire process of analysing and evaluating potential risk. In the professionally sceptical attitude construct, auditors must (at a minimum) include beliefs about risk associated with the conducting audit. Risk assessment should be viewed as the primary component of the professional sceptical attitude since audit standards propose that the nature and extent of audit procedures are to be planned, designed, and/or selected based on the audit teams' risk assessment [46]. Brown-Liburd et al. [47] associated professional scepticism with the auditors' explicit consideration or acknowledgment of risk factor. Carpenter et al. [25] also stated that risk assessment is used as a proxy for professional scepticism. All research acknowledged the significance of risk beliefs or assessment as one indicator of auditors' professional scepticism.

\section{Hypothesis Development}

\subsection{Competence}

Competence influences auditors' professional scepticism. A research by Suraida [48] showed that competence has a positive effect on the auditor's 
professional scepticism. This research was also supported by Lazarusli and Ratri [9]. Carpenter et al. [25] also proved that novice auditors who have a respectable knowledge of fraud have the capability to identify fraud better than auditors who lack such knowledge. Auditors with a high level of competence (has a lot of knowledge and experience in audit) will be more precise and critical of the evidence or information provided [49]. Nelson [4] indicated that professional scepticism can be heightened if auditors have a respectable knowledge about the occurrences of errors and non-errors and the patterns of evidence that indicate risk of misstatement. Moreover, Libby and Fredrick [27] discovered that experienced auditors can produce a broader variety of hypotheses to support and explain audit findings.

However, as mentioned previously, there are arguments from several researchers who believed that there is no significant difference across the level of auditors' competence towards auditors' professional scepticism. For example, Noviyanti and Winata [35] showed that if auditors have a weak sceptical attitude, knowledge of fraud does not influence their professional sceptical behaviour. Auditors with a high level of experience tend to consider non-errors as the more preferred explanations for audit findings [41] and can possibly compromise professional scepticism [43]. Therefore, based on the above clarification, the first hypotheses are formulated as follows:

H1(a): There are significant differences between level of auditors' knowledge and auditors' professional scepticism.

H1(b): There are significant differences between level of auditors' experience and auditors' professional scepticism.

\subsection{Trust}

The general idea is that auditors with a sceptical character have a lower level of trust, e.g. [10,5]. Auditors are expected to be more sceptical when they have a lower level of trust and if they act accordingly. Rose [50] and Quadackers [18] stated that trust is significantly associated with sceptical assessments. An auditor with low confidence in the evidence provided will give it more attention and tend to believe that a misstatement has occurred. Kopp et al. [17] stated that the low level of auditor's trust (confidence) against the client will enhance the auditors' sceptical attitude and vice versa. Moreover, some researchers claimed that trust and professional scepticism are likely to be related although both might be different constructs, e.g., [19,51-53].

However, other researchers argued that there is a possibility of positive relationship between both variables. The argument is that distrust and trust are two different phenomena, i.e., one can be distrusting and trusting at the same time, e.g. [54,55]. This can indicate that auditors can still be distrusting and show sceptical behaviour, while also have a high level of trust [54,55]. Auditors are exposed to many client situations. Thus, their judgements may not depend on their general disposition to trust. Since there is inconsistency in the type of relationship between trust and professional scepticism, this study then provides the following hypotheses:

H2: There is a significant relationship between auditors' trust and professional scepticism

\subsection{Locus of Control}

A person who has an internal locus of control is identified as more depending on his hopes on himself than on a favourable situation. Robbins and Judge [57] described internal locus of control as the level to which individuals believe that they determine their own fate. When an auditor is expected to have an internal locus of control, he is confident that he will be able to solve a problem and evaluate the evidence in detail supported by his professional skills. This research is supported by a study conducted by Lazarusli and Ratri [9] and Clark and Schurer [10]. In addition, previous studies also found that auditors with internal locus of control have a greater level of organizational commitment and will report any misstatement to enhance the quality of the audit.

In contrast, a person with external locus of control believes that the outcomes of the events are uncontrollable and that they rely on luck, fate, chance, or powerful institutions. External locus of control may reduce job performance and personal accomplishments, and the probability of wrong decision making can happen. To add in, Kalbers and Fogarty [58] found that individuals with an external locus of control are exposed to stress as compared to individuals with internal locus of control in demanding conditions. From the above arguments, the third hypotheses are formulated as follows:

H3(a): There is a significant relationship between internal locus of control and auditors' professional scepticism.

H3(b): There is a significant relationship between external locus of control and auditors' professional scepticism.

\subsection{Fraud Risk Assessment}

Auditors should assess the risks of material misstatement in the financial statements and consider performing fraud risk assessment in the designing and implementation of audit procedures. In making this assessment, the auditor should consider the risk factors associated with fraud that arise from fraudulent financial reporting misstatements or the improper treatment of assets. An auditor should assess the risks of material misstatement due to fraud irrespective of whether he/she had planned to assess the inherent risk or control risk at the maximum level. When the level of fraud risk assessment carried out by the auditor is high, then it will heighten the auditor's sceptical attitude to find evidence of fraud because the 
auditor would become more suspicious of the evidence. Conversely, if the level of fraud risk assessment is low, the auditors will tend to be less sceptical to find evidence of fraud.

In Noviyanti and Winata [35], auditors who assessed a high level of fraud risk are found to be more sceptical than the auditors who assessed a low level of fraud risk. Also, Quadackers [18] explains that a high level of fraud risk assessment by auditors are more sceptical than the auditor who are given the low-level fraud risk assessment. Based on the above arguments, the fourth hypothesis examines whether the estimated risk of fraud affects the level of auditor's professional scepticism and is formulated as follows:

H4: There is a significant relationship between auditors' fraud risk assessment and auditor's professional scepticism

\section{Methodology}

The respondents for this study are practising auditors who work with audit firms registered with MIA in Kuala Lumpur. 381 research questionnaires were distributed, and this study managed to receive 127 usable questionnaires to be analysed which represents a response rate of 33.33 percent. The questionnaire consists of four parts with each measurement item using a six-point Likert scale $(1=$ strongly disagree to $6=$ strongly agree) and the final part collects the respondent's demographic profile.

- Part One covers 30 questions of Hurtt [19] Professional Scepticism Scale which examines the level of an auditor's scepticism and measures constructs that are closely related to one or more of the six elements of scepticism (curiosity, self-confidence, interpersonal understanding, questioning, self-determining, and deliberating).

- Part Two includes 8 questions to estimate auditors' general willingness to trust other people.

- Part Three encompasses 16 questions to measure the locus of control orientation in the workplace, whether it is internal or external, where half of them focused internal locus of control and the other half on external locus of control.

- Part Four comprises 10 questions to measure the level of agreement for each of the statements regarding fraud risk assessment.

- Part Five collects the demographic profile of the respondents which included age, gender, race, level of education, years of audit experience, and the professional position of the respondent.

\section{Findings and Discussion}

\subsection{Profile of Respondents}

Most of the respondents of this study, 76 out of 127 , were 59.8 percent female while 51 respondents were male who made up the remaining 40.2 percent of the sample. Most of the respondents aged 30 years old or less at 87.4 percent, while the lowest percentage was at 1.6 percent with 50 years old and above. For the job positions, 73.2 percent or 93 of the respondents are junior auditors, while the remaining are senior auditors, senior audit supervisors, audit partners, and audit managers which comprise about 26.8 percent.

The ethnic breakdown of the respondents also showed that the majority are Malays at 81.9 percent. Chinese and Indians comprise 16.5 percent and 1.6 percent, respectively. Additionally, from this analysis, 78 of the respondents are degree holders at 61.4 percent while four master holders make up 3.1 percent. The remaining 15 (11.8\%) respondents hold diploma certificates and $30(23.6 \%)$ have professional memberships. The percentages show low professional membership and master certificate holders because most of the respondents are fresh graduates who do not have enough working experience to be qualified as ACCA or MIA members.

\subsection{Analysis of Variance (ANOVA)}

This analysis is done by referring to the P-value and F-value. Table 1 presents that P-value $(.880)>0.05$ (not significant), which concludes that there is no difference (at $5 \%$ level of significance) in the mean of auditors' professional scepticism among the three levels of education. The $\mathrm{F}$ critical value of the overall mean of auditors' professional scepticism (.128) is less than F observe value $(F 2,124 ; 0.05=3.00)$. This indicates that there is no evidence that at least one level of auditors' education differs from the rest affecting the professional scepticism attitude. Thus, it can be concluded that auditors' level of professional scepticism is not affected by the difference of level of their education (knowledge).

Table 1. Analysis of Variance (ANOVA)

\begin{tabular}{cccc}
\hline Education Level & Mean & F-value & P-value \\
\hline Certificate/Diploma & 4.18 & & \\
Bachelor & 4.23 & .128 & .880 \\
Professional and Master & 4.26 & & \\
\hline
\end{tabular}


Contrastingly, to examine the difference between the levels of auditors' experience that was measured by the auditor's position level toward auditors' sceptical attitude, a t-test is performed. The t-test assesses whether the mean of two groups is statistically different from each other. Due to high percentage of respondents from the category of Junior Auditor (73.2 percent) compared to the percentage of other categories (26.8 percent) as stated in Table 2, the respondents' professional position is divided into two groups which are "Junior Auditor" and "Senior Auditor and above" for the purpose of this analysis.

Table 2 indicates that there is no significant difference in scores for Junior Auditor $(M=4.20, S D=.471)$ and Senior Auditor and above $(M=4.33, S D=.408) ; t(125)=-1.435$, $p=.154$ (two-tailed). The magnitude of the differences in the mean (mean difference $=.13,95 \%$ CI: -.312 to 0.50 ) is very small (eta squared $=.016$ ). Eta squared value of .016 indicates that there is a small effect with minimal difference in the mean scores obtained by "Junior Auditor" and "Senior Auditor and above".

Table 2. Independent SampleT-test

\begin{tabular}{cccccc}
\hline $\begin{array}{c}\text { Auditor's } \\
\text { Position Level }\end{array}$ & Mean & SD & t & df & P-value \\
\hline $\begin{array}{c}\text { Junior Auditor } \\
\text { Senior Auditor and } \\
\text { above }\end{array}$ & 4.20 & .471 & -1.43 & 125 & .154 \\
\hline
\end{tabular}

Besides, P-value (.154) > 0.05 (not significant), which concludes that there is no difference (at $5 \%$ level of significance) in the mean of auditors' professional scepticism between the two groups of auditors' professional positions. Therefore, it can be concluded that auditors' level of professional scepticism is not affected by the difference in level of their professional positions (experience). Based on the results, it can be concluded that H1 (a) and H1 (b) are not supported and are rejected.

\subsection{Correlation Analysis}

Table 3 shows that trust positively and weakly correlates with professional scepticism $(r=.220 ; \mathrm{p}<0.05)$. Even though the correlation is moderately low, this result indicates that on average, the trust is higher at higher auditors' professional scepticism. Professional scepticism positively relates to internal locus of control with a Pearson correlation coefficient of $\mathrm{r}=.370$ and the significance value (.000) is less than .001 . This indicates that there is a genuine relationship between professional scepticism with internal locus of control.

Conversely, professional scepticism negatively relates to external locus of control with a Pearson correlation coefficient of $r=-.128$ and the significance value (.152) is more than .001 . Hence, this result indicates that there is no relationship between professional scepticism with external locus of control since $p>0.01$. Conversely, professional scepticism positively relates to fraud risk assessment with a Pearson correlation coefficient of $\mathrm{r}=.380$ and the significance value (.000) is less than .001 . This indicates that there is a genuine relationship between professional scepticism with auditors' fraud risk assessment.

Table 3. Correlation Analysis

\begin{tabular}{ccc}
\hline & \multicolumn{2}{c}{ Professional Scepticism } \\
\cline { 2 - 3 } & $\begin{array}{c}\text { Pearson Coefficient of } \\
\text { Correlation }(\boldsymbol{r})\end{array}$ & $\boldsymbol{p}$-value \\
\hline Trust & $.220^{*}$ & .013 \\
Internal LOC & $.370^{* *}$ & .000 \\
External LOC & -.128 & .152 \\
Fraud Risk & $.380^{* *}$ & .000 \\
Assessment &
\end{tabular}

* Correlation is significant at the 0.05 level (2-tailed).

** Correlation is significant at the 0.01 level (2-tailed).

\subsection{Regression Analysis}

In this study, multiple regression analysis is used to test the relationships between the auditors' professional scepticism with auditors' trust (H2), locus of control (H3), and fraud risk assessment (H4). Based on Table 4(a), the result shows a significant value at $5 \%(\mathrm{~F}=15.320, \mathrm{p}=.000)$. Therefore, it can be concluded that there is sufficient evidence to show that at least one of the independent variables exists between dependent variables.

Based on Table 4(b), it shows that only trust, internal locus of control, and fraud risk assessment have significant relationships with auditors' professional scepticism. Adjusted $\mathrm{R}^{2}$ indicates the percentage of independent variables that can explain the dependent variables. From the analysis, the adjusted $\mathrm{R}^{2}$ of 0.313 indicates that 31.3 percent of the variation in the professional scepticism can be explained by trust, locus of control, and fraud risk assessment. The coefficient for trust is $.228, \mathrm{t}=2.222, \mathrm{p}=$ 0.015 . The trust result shows that there is a significant positive relationship between auditors' trust and professional scepticism at $\mathrm{p}<.05$. Therefore, hypothesis $\mathrm{H} 2$ is supported. This result indicates that for every 1 rise in the trust, it can enhance professional scepticism by 0.228 , net of the effects of changes due to other independent variables.

To add in, the coefficient for internal locus of control is $.303, \mathrm{t}=3.375, \mathrm{p}=.000$ where $\mathrm{p}<.05$ indicates that the result supports hypothesis $\mathrm{H} 3(\mathrm{a})$. This result indicates that for every 1 rise in the internal locus of control, it can enhance the professional scepticism by 0.303 , net of the effects of changes due to other independent variables. Conversely, hypothesis H3(b) predicted that external locus of control has a significant relationship on professional scepticism but this hypothesis is rejected because there is no significant relationship with $\mathrm{p}=.391(\mathrm{p}>.05)$.

Lastly, hypothesis $\mathrm{H} 4$ proposed that fraud risk assessment has a significant positive relationship with professional scepticism. Table 4(b) provides evidence that the coefficient for fraud risk assessment is .427 with the $\mathrm{p}$-value of .000 which indicates that there is a significant positive relationship between fraud risk assessment and 
professional scepticism among auditors. Therefore, $\mathrm{H} 4$ is accepted as fraud risk assessment may contribute to auditors' professional scepticism. This result also indicates that for every 1 rise in the low fraud risk assessment, it can increase professional scepticism by 0.427 , net of the effects of changes due to other independent variables.

Table 4(a). Regression Analysis

\begin{tabular}{cccccc}
\hline Model & $\begin{array}{c}\text { Sum of } \\
\text { Squares }\end{array}$ & df & $\begin{array}{c}\text { Mean } \\
\text { Square }\end{array}$ & F & Sig. \\
\hline Regression & 8.819 & 4 & 2.205 & 15.320 & $.000^{\mathrm{b}}$ \\
Residual & 17.557 & 122 & .144 & & \\
\hline Total & 26.376 & 126 & & & \\
\hline
\end{tabular}

a. Dependent Variable: Overall mean for professional scepticism

b. Predictors: (Constant), Overall mean for auditor's fraud risk, Overall mean for work locus (internal), Overall mean for work locus (external), Overall mean for trust

Table 4(b). Regression Analysis

\begin{tabular}{ccccc}
\hline Model & $\begin{array}{c}\text { Standardized } \\
\text { Coefficients }\end{array}$ & $\begin{array}{c}\text { Std. } \\
\text { Error }\end{array}$ & t-stat & p-value \\
\hline $\begin{array}{c}\text { Constant } \\
\text { Trust }\end{array}$ & .228 & .447 & & \\
$\begin{array}{c}\text { Internal } \\
\text { Locus of } \\
\text { Control }\end{array}$ & .303 & .076 & 2.222 & .015 \\
$\begin{array}{c}\text { External } \\
\text { Locus of } \\
\text { Control }\end{array}$ & -.077 & .048 & .000 \\
$\begin{array}{c}\text { Fraud Risk } \\
\text { Assessment }\end{array}$ & .427 & .046 & -1.237 & .391 \\
\hline \multicolumn{5}{c}{$\mathrm{R}$} \\
\end{tabular}

\section{Discussion of the Findings}

Based on the descriptive analysis results, it shows that most of the respondents who are fresh junior auditors had problems in understanding and applying professional scepticism due to a lack of sensitivity. On the ANOVA analysis, it was found that there is no significant difference on the level of auditors' professional sceptical attitude with the different levels of auditor's knowledge and experience. This means that auditors' level of professional scepticism is not affected by the different levels of their education (knowledge) and professional position (experience). Therefore, H1(a) and H1(b) are rejected. The result is supported by a study from Noviyanti and Winata [35] which indicated that knowledge of fraud does not influence auditors' professional sceptical behaviour if they have a weak sceptical attitude. To add in, the study from Kaplan et al. [36] stated that auditors with a high level of experience are more expected to consider that non-errors are the more likely explanations for audit findings and can possibly compromise professional scepticism [38]. The result is also consistent with the study from Shaub and Lawrence [39] which indicated that auditors who are more experienced have greater expectation that non-errors describe audit findings.

Based on the results from the correlation and regression analyses, it is discovered that there is moderate positive relationship for both variables although it (correlation) is low. An explanation of the positive relationship between both variables is the argument of several researchers that distrust and trust are two different phenomena, i.e., one can be distrusting and trusting at the same time, e.g., $[54,55]$. This indicates that auditors can still be distrusting and show sceptical behaviour, while also have a high level of trust. Therefore, $\mathrm{H} 2$ is accepted. Overall, this finding is also consistent with the findings from the study by Kopp et al. [17] which stated that confidence (trust) in the auditor-client relationship will affect professional scepticism.

Furthermore, it is discovered that there is a significant positive relationship between professional scepticism and internal locus of control. However, the result also discovered that there is no significant relationship between professional scepticism and external locus of control. Therefore, H3(a) is accepted and H3(b) is rejected. Both results are consistent which indicated that auditors with internal locus of control are allied with a higher degree of overall job performance because of their ability to effectively control the audit environment by identifying the issues as compared to those with external locus of control. This means that auditors with an internal locus of control tend to be more sceptical in their judgements and actions compared to auditors with external locus of control who believe that their destinies are controlled by external factors, such as chance, fate, luck, and power [14].

The result also stated that if the assessment of risk fraud assessment is low, the auditors' professional scepticism will significantly decrease and vice versa. Therefore, $\mathrm{H}(4)$ is accepted. The finding is consistent with the study from Nelson [4] who mentioned that professional scepticism is indicated by auditors' judgments and decisions which reflect an intensified risk assessment that an assertion is incorrect, provisional on the evidence available to the auditors. The result is also consistent with a study by Abičić [59] who discovered that auditor's sceptical attitude which is influenced by information of low-level risk assessment in the planning phase results in a decrease in auditor's scepticism.

\section{Conclusions}

On conclusion, the findings of this study can be summarized that only auditors' trust (H2), internal locus of control (H3(a)), and fraud risk assessment (H4) have a significant relationship with auditors' professional scepticism. All hypotheses are supported by the results generated from the above-mentioned analyses. Conversely, it was found that there is no significant difference on the 
level of auditors' professional sceptical attitude due to the different levels of auditor's knowledge and experience (H1(a) and H1(b)). Thus, auditors' level of professional scepticism is not affected by the different levels of their education (knowledge) and professional position (experience). Additionally, the results stated that external locus of control (H3(b)) have no significant relationship with auditors' professional scepticism.

These findings offer essential understanding to the auditing profession and scholars on the factors that could be used to enhance the auditors' professional scepticism. It is proven that both the individual factors, i.e. auditors' competence, trust and locus of control, as well as environment factor i.e. fraud risk have strong influences on the professional scepticism. Thus, these could help the profession in identifying possible actions or remedy any existing factors surrounded the auditors' working environment. In addition, the results from this study are expected to be used as a guideline to the Malaysian audit practitioners to emphasize these relevant factors that could practically influence their degree of professional scepticism. This study is also important especially for Malaysian audit firms and professional bodies to promote professional scepticism as a standard practice and also as part of the professional culture of the firm thus heightening auditors' sceptical attitude in order to enhance audit quality.

\section{Limitations and Recommendations}

Most of the respondents are fresh graduates or junior auditors who do not have much audit working experience and lack the knowledge regarding this issue. The problem arises due to a lack of understanding about professional scepticism which may have resulted in inappropriate responses/answers in the survey conducted. Additionally, this survey was conducted during the audit peak period (March to April 2019) when most of the audit firms were busy conducting their audit activities. Thus, there was less participation from auditors in the category of Senior Auditors and above.

Another limitation concerns the distribution of the questionnaires. In this study, questionnaires were distributed via mail, e-mail, or online through a provided URL link, which caused numerous problems. It would have been better if the questionnaires were given by hand. When the questionnaires were sent by through the provided URL link, it was difficult to ensure that the targeted subjects answered the questionnaires. There was no guarantee that the mail, e-mail, or online response (through e-mail or WhatsApp application) would be returned and that the answers were truthful and meaningful to the survey.

Further studies on professional scepticism should attempt to employ a wider range of participants (auditors) in Malaysia to validate the reliability of the scale and improve the validity of the findings. Moreover, to obtain more reliable data, another method or instrument that can be used to gauge auditor's professional scepticism is through face-to-face interview with the different categories of auditors. This allows more information to be obtained as the auditors can relate their real-life experiences and challenges on professional scepticism when carrying out audit work. Hence, more authentic data can be collected.

Future studies should also consider a comparison between large and smaller accounting firms' auditors toward the sceptical attitude. Additionally, the current study may be extended to other accounting professionals such as internal auditors and tax professionals as it appears to be relevant and appropriate for research.

\section{REFERENCES}

[1] M. S. Beasly, J. V. Carcello, D. R. Hermanson, "Top 10 Audit Deficiencies," Journal of Accountancy, vol. 19, no. 1, pp. 63-66, 2001.

[2] Y. M. Hamshari, H. Y. Ali, M. A. Alqam, "The Relationship of Professional Skepticism to the Risks of Auditing and Internal Control, and the Discovery of Fraud and Core Errors in the Financial Statements in Jordan," Academic Journal of Interdisciplinary Studies, vol. 10, no. 2, pp. 105-117, 2021.

[3] R. K. Hurtt, "Professional Skepticism: An Audit Specific Model and Measurement Scale," Working Paper, Baylor University, 2007.

[4] M. Nelson, "A Model and Literature Review of Professional Scepticism in Auditing," Auditing: A Journal of Practice \& Theory, vol. 28, no. 2, pp. 1-34, 2009.

[5] R. Coppage, T, Shastri, "Effectively Applying Professional Skepticism to Improve Audit Quality," The CPA Journal, vol. 84 , no. 8, pp. 24-28, 2014.

[6] J. B. Rotter. "A New Scale for the Measurement of Interpersonal Trust," Working Paper, University of Connecticut, Journal of Personality, vol. 35, pp. 651-665, 1967.

[7] J. B. Rotter, "Interpersonal Trust, Trustworthiness, and Gullibility,” American Psychologist, vol. 35, no. 1, pp. 1-7, 1980.

[8] M. K. Shaub, "Trust and Suspicion: The Effects of Situational and Dispositional Factors on Auditors' Trust of Clients," Behavioral Research in Accounting, vol. 8, pp. 154-174, 1996.

[9] Lazarusli, D. D. Ratri, "Factors Affecting Professional Skepticism Auditor," Working Paper, Katolik Soegijapranata University, 2011.

[10] D. A. Cobb-Clark, S. Schurer, "Two Economists' Musings on the Stability of Locus of Control," The Economic Journal, vol. 123, no. 570, pp. F358-F400, 2013.

[11] E. K. Nyhus, E. Pons, "The effects of personality on 
earnings," Journal of Economic Psychology, vol. 26, no. 3, pp. 363-384, 2004.

[12] J. B. Rotter, "Generalized Expectancies for Internal versus External Control of Reinforcement," Psychological Monographs: General and Applied, vol. 80, no. 1, pp. 1-28, 1966.

[13] L. K. Trevino, "Ethical Decision Making in Organization: A Person-Situation Interactionist Model," Academy of Management Review, vol. 11, no.3, pp. 601-617, 1986.

[14] V. B. Hoffman, J. M. Patton, "Accountability, the Dilution Effect, and Conservatism in Auditors' Fraud Judgments," Journal of Accounting Research, vol. 35, no. 2, pp. 227-237, 1997.

[15] R. L. Braun, "The effect of Time Pressure on Auditor Attention to Qualitative Aspects of Misstatements Indicative of Potential Fraudulent financial Reporting," Accounting, Organizations and Society, vol. 25, pp. 243-259, 2000

[16] E. A. Payne, R. J. Ramsay, "Fraud Risk Assessments and Auditors' Professional Scepticism," Managerial Auditing Journal, vol. 20, no. 3, pp. 321-330, 2005.

[17] L. Kopp, W. M. Lemon, M. Rennie, "A Model of Trust and Professional Skepticism in the Auditor-Client Relationship," Working Paper, University of Waterloo, 2003.

[18] L. M. Quadackers, “The Relationship between Auditors' Interpersonal Trust Factors, Professional Rank and Skeptical Judgments and Decisions," Working Paper, VU University Amsterdam, 2009.

[19] R. K. Hurtt, "Development of a Scale to Measure Professional Skepticism," Auditing: A Journal of Practice and Theory, vol. 29, no. 1, pp. 149-171, 2010.

[20] S. A. H. Hussin, T. M. Iskandar, "Re-Validation of Professional Scepticism Traits," Procedia Economics and Finance, vol. 28, pp. 68-75, 2015.

[21] M. Deutsch, "Trust and suspicion," Journal of Conflict Resolution, vol. 2, pp. 265-279, 1958.

[22] K. Jamal, P. E. Johnson, R. G. Berryman, "Detecting Framing Effects in Financial Statements," Contemporary Accounting Research, vol. 12, no. 1, pp. 85-105, 1995.

[23] M. F. Zimbelman, "The Effects of SAS No. 82 on Auditors' Attention to Fraud Risk Factors and Audit Planning Decisions," Journal of Accounting Research, vol. 35, Supplement, pp. 75-97, 1997.

[24] R. K. Hurtt, C. E. Brown-Liburd, G. Krishnamoorthy, "Research on Auditor Professional Scepticism: Literature Synthesis and Opportunities for Future Research," Auditing: A Journal of Practice \& Theory, vol. 32, Supplement 1, pp. 45-97, 2013.

[25] T. Carpenter, C. Durtschi, L. M. Gaynor, "The Role of Experience in Professional Scepticism, Knowledge Acquisition and Fraud Detection," American Accounting Association Mid-Year Auditing Meeting, 2002.

[26] R. Libby, "Availability and the Generation of Hypotheses in Analytical Review," Journal of Accounting Research, vol. 23, no. 2, pp. 648-667, 1985.
[27] R. Libby, D. M. Frederick, "Experience and the Ability to Explain Audit Fndings," Journal of Accounting Research, vol. 28, no. 2, pp. 348-367, 1990.

[28] A. Herawaty, Y. K. Susanto, "Profesionalisme, Pengetahuan Akuntan Publik dalam Mendeteksi Kekeliruan, Etika Profesi dan Pertimbangan Tingkat Materialitas," Jurnal Akuntansi dan Keuangan, vol. 11, no. 1, 2011.

[29] P. T. Hai, L. D. Toanc, N. L. D. Quy, N. T. Tung, "Research Factors Affecting Professional Skepticism and Audit Quality: Evidence in Vietnam," International Journal of Innovation, Creativity and Change, vol. 13, no. 1, pp. $830-847,2020$

[30] D. Deliu, "Elevating Professional Reasoning in Auditing. Psycho-Professional Factors Affecting Auditor's Professional Judgement and Skepticism," Journal of Accounting and Auditing: Research \& Practice, vol. 2020, ISSN: $2165-9532$ DOI: $10.5171 / 2020.804680$

[31] S. Wright, A. M. Wright, "The Effect of Industry Experience on Hypothesis Generation and Audit Planning Decisions," Behavioral Research in Accounting, vol. 9, pp. 273-294, 1997.

[32] V. E. Owhoso, W. F. Messier, J. G. Lynch, "Error Detection by Industry-Specialized Teams During Sequential Audit Review," Journal of Accounting Research, vol. 40, no. 3, pp. 883-900, 2002.

[33] K. Y. Low, "The effects of Industry Specialization on Audit Risk Assessments and Audit-Planning Decisions," The Accounting Review, vol. 79, no. 1, pp. 201-219, 2004.

[34] J. C. Bedard, A. L. Hartgraves, "Enron: What Happened and What We Can Learn from It," Journal of Accounting and Public Policy, vol. 21, no. 2, pp. 105-127, 2002.

[35] S. Noviyanti, L. Winata, "The Role of 'Tone at The Top' and Knowledge of Fraud on Auditors' Professional Skeptical Behavior," Contemporary Management Research, vol. 11, pp. 55-74, 2015.

[36] S. E. Kaplan, C. Moeckel, J. D. Williams, "Auditors' Hypothesis Plausibility Assessments in Analytical Review Setting," Auditing: A Journal of Practice \& Theory, vol. 11, 1992.

[37] T. D. Ratna, I. Anisykurlillah, "The Effect of Experience, Independence, and Gender on Auditor Professional Scepticism with Professional Ethics as Moderating," Accounting Analysis Journal, vol. 9, no. 2, pp. 138-145, 2020 .

[38] L. Koonce, "A Cognitive Characterization of Audit Analytical Review," Auditing: A Journal of Practice \& Theory, vol. 12, Supplement, pp. 57-76, 1992.

[39] M. K. Shaub, J. E. Lawrence, "Differences in Auditors' Professional Skepticism Across Career Levels in the Firm,' Advances in Accounting Behavioral Research, vol. 2, pp. 61-83, 1999.

[40] G. Erlane, R. Harianto, D. J. Tjahjo, Y. M. Mohd, "The Influence of Professional Scepticism, Self-Efficacy and Perceived Ethical Climate on Internal Auditors' Ethical Judgment in Public Sector Management," Polish Journal of Management Studies, vol. 19, no. 2, pp. 155-166, 2019.

[41] K. A. Graham, “Auditor Personal Characteristics and Fraud 
Detection Skills: The Mediating Role of Professional Scepticism," Ph.D. thesis, University of Ghana, 2019.

[42] H. W. Kee. R. E. Knox, "Conceptual and Methodological Considerations in the Study of Trust and Suspicion," Journal of Conflict Resolution, vol. 14, pp. 357-366, 1970.

[43] R. J. Johari, M. M. Alam, J. Said, "Investigating Factors that Influence Malaysian Auditors Ethical Sensitivity," International Journal of Ethics and Systems, vol. 37, no. 3, pp. 406-421, 2021. DOI: 10.1108/IJOES-01-2021-0006

[44] J. Tsui, F. A. Gul, "Auditors' Behaviour in an Audit Conflict Situation: A Research Note on the Role of Locus of Control and Ethical Reasoning," Accounting, Organizations and Society, vol. 21, no. 1, pp. 41-51, 1996.

[45] D. Donnelly, J. Quirin, D. O’Bryan, “Auditor Acceptance of Dysfunctional Behavior: An Explanatory Model Using Auditors' Personal Characteristics," Behavioral Research in Accounting vol. 15, pp. 87-110, 2003.

[46] Public Company Accounting Oversight Board, "Report on Observations of PCAOB Inspectors Related to Audit Risk Areas Affected by the Economic Crisis," Release No. 2010-006, Washington DC, 2010.

[47] H. Brown-Liburd, J. Cohen, G. Trompeter, "Effects of Earnings Forecasts and Heightened Professional Scepticism on the Outcomes of Client-Auditor Negotiation," Journal of Business Ethics vol. 116, no. 2, pp. 311-325, 2011.

[48] I. Suraida "The Influence of Ethics, Competence, Experience Audit and Risk Audits Toward Auditor Professional Skepticism and Precision Opinion Granting Public Accountant," 2005.

[49] R. A. Lamba, Y. C. Seralurin, A. Lamba, V. Pattiasina, "The Effect of Auditor Independence and Ethics on Auditor Professional Scepticism: Its Implications for Audit Quality in Indonesia," International Journal of Innovation, Creativity and Change, vol. 12, no. 8, pp. 383-396, 2020.
[50] J. M. Rose, “Attention to Evidence of Aggressive Financial Reporting and Intentional Misstatement Judgments: Effects of Experience and Trust," Behavioral Research in Accounting, vol. 19, pp. 215-229, 2007.

[51] V. Popova, "The Influence of Skepticism and Previous Experience on Auditor Judgments,” Working Paper, 2006.

[52] M. D. Rennie, L. S. Kopp, W. M. Lemon, "Exploring Trust and the Auditor-Client Relationship," Working Paper, 2007.

[53] M. S. Doucet, T. A. Doucet, "Commentary on Ethics, Experience and Professional Skepticism: A Situational Analysis," Behavioral Research in Accounting, vol. 8, Supplement, pp. 158-168, 1996.

[54] D. H. McKnight, N. L. Chernavy, "Trust and Distrust Definitions: One Bite at a Time, in Trust in Cyber-societies," eds. R. Falcone, M. Singh, Y. H. Tan, pp. 27-54, Spinger Verlag, Berlin, 2001.

[55] W. M. Webb, P. Worchel, "Trust and Distrust, in Psychology of Intergroup Relations," eds. S. Worchel, W. G. Austin, Nelson-Hall Publishers, Chicago, 1986.

[56] K. Kamil, N. Fathonah, "The Effect of Independence, Integrity, Professionalism, and Professional Skepticism on the Accuracy of Giving Audit Opinion (The Case of Audit Board of the Republic of Indonesia)," Advances in Economics, Business and Management Research, vol. 127, pp. 5-10, 2019

[57] S. P. Robbins, T. A. Jugde, "Organizational Behavior, Pearson Education,” lnc., New Jersey, 2007.

[58] L. P. Kalbers, T. J. Fogarty, "Antecedents to Internal Auditor Burnout," Journal of Managerial Issues, vol. 17, no. 1, pp. 101-118, 2005.

[59] S. P. Abičić, "Professional Skepticism of Auditors and Risk of Fraudulent Financial Reporting." Journal of Accounting and Management, Original Scientific Paper, UDC 657.6, 2014. 